\title{
Biology of Isopisthus parvipinnis: an abundant sciaenid species captured bycatch during sea-bob shrimp fishery in Brazil
}

\author{
Renato M. Romero', Leonardo E. Moraes², Marcella N. Santos ${ }^{3}$, \\ Gecely R. A. Rocha ${ }^{4}$ and Mauricio Cetra ${ }^{5}$
}

Trawling is the most common method of shrimp harvesting. This technique causes a negative impact on the fauna due to the high bycatch rates and to the animals that are accidentally caught and generally returned to the sea dead. The consequences of this technique and the biological aspects of the involved species are poorly studied, specially in the Brazilian northeast. The objective of this study was to show some aspects of the population biology of Isopisthus parvipinnis (Bigtooth corvina) captured as bycatch during sea-bob (Xiphopenaeus kroyeri) shrimp fishing in the region of Ilhéus, in the state of Bahia in Brazil. A total of 1290 individuals were caught in a monthly sampling at three different stations, from March, 2003 to February, 2005. The standardized Morisita index of dispersion suggests that this species has a clumped distribution in the studied area. The number of individuals showed a significant variation $(\mathrm{p}<0.0001)$ between the seasons, being higher during the winter. The estimated first maturation length $\left(\mathrm{L}_{50}\right)$ was about $159 \mathrm{~mm}$, and $95 \%$ of the captured individuals were below this value. The sexual ratio found was 1.5 males for each female. Concerning to diet, 10 feeding categories were identified, and Decapoda Dendobranchiata was the most important in numeric frequency and occurrence. This fact suggests that Isopisthus parvipinnis is a carnivorous species, with a tendency toward crustacean-eating at least in the younger individuals.

A pesca de arrasto é o método mais comum de captura de camarão. Esta técnica causa impactos negativos na fauna demersal devido ao grande número de animais que são capturados acidentalmente e que geralmente são devolvidos mortos ao mar. As conseqüências desta metodologia de pesca e os aspectos biológicos das espécies envolvidas são pouco estudados, especialmente no Nordeste do Brasil. Este estudo tem como objetivo mostrar aspectos biológicos de Isopisthus parvipinnis (tortinha) capturada como fauna acompanhante da pesca do camarão sete barbas (Xiphopenaeus kroyeri) na região de Ilhéus, no estado da Bahia, Brasil. Um total de 1290 indivíduos foram capturados em coletas mensais, em três pontos de coleta distintos, de março de 2003 a fevereiro de 2005. O índice de dispersão de Morisita padronizado sugere que a espécie, na área analisada, apresenta uma distribuição agregada. O número de indivíduos variou significativamente entre as estações do ano (p $<0,0001)$, sendo maior durante o inverno. O comprimento estimado de primeira maturação $\left(\mathrm{L}_{50}\right)$ foi de $159 \mathrm{~mm}$, sendo que $95 \%$ dos indivíduos capturados estavam abaixo deste valor. A razão sexual encontrada foi de 1,5 machos para cada fêmea. Quanto à dieta, foram identificadas 10 categorias alimentares, sendo que Decapoda Dendobranchiata foi a mais importante em freqüência numérica e de ocorrência. Este fato sugere que Isopisthus parvipinnis é uma espécie carnívora, com tendência a carcinofagia, ao menos nos indivíduos jovens.

Key words: Biometric relationships, Inner shelf, Brazilian northeast.

\footnotetext{
${ }^{1}$ Programa de Pós-Graduação em Zoologia Aplicada. Departamento de Ciências Biológicas. Universidade Estadual de Santa Cruz (UESC), Rodovia Ilhéus-Itabuna, km 16, $45662-000$ Ilhéus, BA, Brazil. Present address: UNESP - Universidade Estadual Paulista, Laboratório de Ictiologia, Departamento de Zoologia e Botânica, IBILCE, rua Cristóvão Colombo 2265, Jardim Nazareth, 15054-000 São José do Rio Preto, SP, Brazil.romerobio@yahoo.com.br

${ }^{2}$ Programa de Pós-Graduação em Sistemas Aquáticos Tropicais. DCB. UESC. Ilhéus, BA, Brazil. lemoraes6@yahoo.com.br

${ }^{3}$ Ciências Biológicas. DCB. UESC. Ilhéus, BA, Brazil.marcella_nunes@yahoo.com.br

${ }^{4}$ Departamento de Ciências Biológicas. UESC. Ilhéus, BA, Brazil. gecely@uesc.br

${ }^{5}$ Departamento de Ciências Exatas e Tecnológicas. UESC. Ilhéus, BA, Brazil. mcetra@uesc.br
} 


\section{Introduction}

Trawling is a very efficient but non-selective method of harvesting aquatic resources, because results in the accidental capture of large quantities of individuals that are sympatric to the target species, which together are called bycatch (Alverson et al., 1994; Perez et. al., 2001; Vianna, 2001). It is composed of immature and/or small individuals who are discarded because they have no commercial value. Fish species are generally the most abundant in number of individuals and biomass when compared to other groups, representing almost $70 \%$ of the bycatch (Coelho et al., 1986; Haimovici \& Mendonça, 1996; Santos, 2000; Branco, 2001; Graça Lopes et al., 2002).

The Sciaenidae family is relatively abundant in this kind of fishery. Some species are found in estuarine regions, and others are strictly freshwater species, but the majority is found in shallow waters of the continental shelf over sand and mud flats or in coral reefs. They constitute one of the most important costal demersal fishing resources of the Atlantic (Menezes \& Figueiredo, 1980; Cervigón et al., 1992).

The species Isopisthus parvipinnis (Cuvier, 1830) (Osteichthyes: Sciaenidae) comprises one of the main bycatch elements of Xiphopenaeus kroyeri (Heller, 1862) shrimp trawl fisheries in Brazil (Coelho et al., 1986; Paiva-Filho \& Schmiegelow, 1986). Popularly known as "tortinha," it has low commercial interest and is generally used as bait. It is distributed from Costa Rica to the south of Brazil, in costal waters with an average depth of up to 50 meters (Menezes \& Figueiredo, 1980; Cervigón et al., 1992; Carpenter, 2002).

Studies on distribution, abundance and population growth of species exploited by fishing allow data to be obtained regarding the effect on non-target resources (Vianna et al., 2000). Furthermore, they can contribute to the formulation of fishery management plans and policies in favor of a better utilization of the catches (Gulland, 1966). Research regarding biological aspects of I. parvipinnis has been conducted in the southern (Coelho et al., 1988; Chaves et al., 1998; Chaves et al., 2003) and south-eastern regions (Soares, 1989; Giannini \& Paiva-Filho, 1994; Soares \& Vazzoler, 2001) of Brazil, but there are no studies on this species in northeastern area. Especially in this region, the continental shelf is very close (about $32 \mathrm{~km}$ ) (França, 1979), and because of this the low depth trawling is concentrated in few areas, possibly increasing the impacts.

In this context, the main aim of the present study was to provide information on the biology of I. parvipinnis on the coast of Ilhéus, Bahia, Brazil, contributing to the broad, current knowledge of this species, and based on this to propose non-fishing alternative periods for the shrimp fisheries.

\section{Material and Methods}

The city of Ilhéus is located in the south of the state of Bahia (14 $\left.46^{\prime} \mathrm{S} 39^{\circ} 02^{\prime} \mathrm{W}\right)$ in Brazil. The main rivers that cross the city are the Almada (Almada sub-basin), Cachoeira, Fundão and Santana (Colônia/Cachoeira sub-basin) (Bahia, 2001). The climate is hot and permanently humid, without a dry season. The average rainfall is $1716.6 \mathrm{~mm} /$ year with an evaporation of $1469.6 \mathrm{~mm} /$ year. The average annual temperature is $23.3^{\circ} \mathrm{C}$, with a minimum of $19.4^{\circ} \mathrm{C}$ and a maximum of $28.5^{\circ} \mathrm{C}$ (Bahia, 2001). The coast of Ilhéus is situated within the trade wind belt of the South Atlantic (NE - E - SE), which is related to a high-pressure cell. Seasonally, this high-pressure cell tends to expand and contract. During the winter, the highpressure zone covers a vast area over the continent, whereas during the summer it returns to the ocean. On the coastal zone, this seasonal movement controls the position of the Divergence Zone (DZ), between the trade winds sensu stricto (SE) and the returning trade winds (NE). During the winter, due to the fact that the $\mathrm{DZ}$ is located at approximately $20^{\circ} \mathrm{S}$, winds coming from the SE and $\mathrm{E}$ arrive at the coast of Ilhéus. Moreover, during this period the winds arising from the SSE, associated with the periodic advance of the Atlantic polar front, reinforce the trade winds from the SE. During the summer, the position changes to approximately $13^{\circ} \mathrm{S}$. Therefore, the coast of Ilhéus could be reached by winds arising from the NE and E. These temporal changes in the wind regime cause alterations in the predominant wave fronts of the region (Dominguez \& Bittencourt, 1994; Martin et al. 1998; Bittencourt et al., 2000).

The continental shelf off the study area shows a reduced

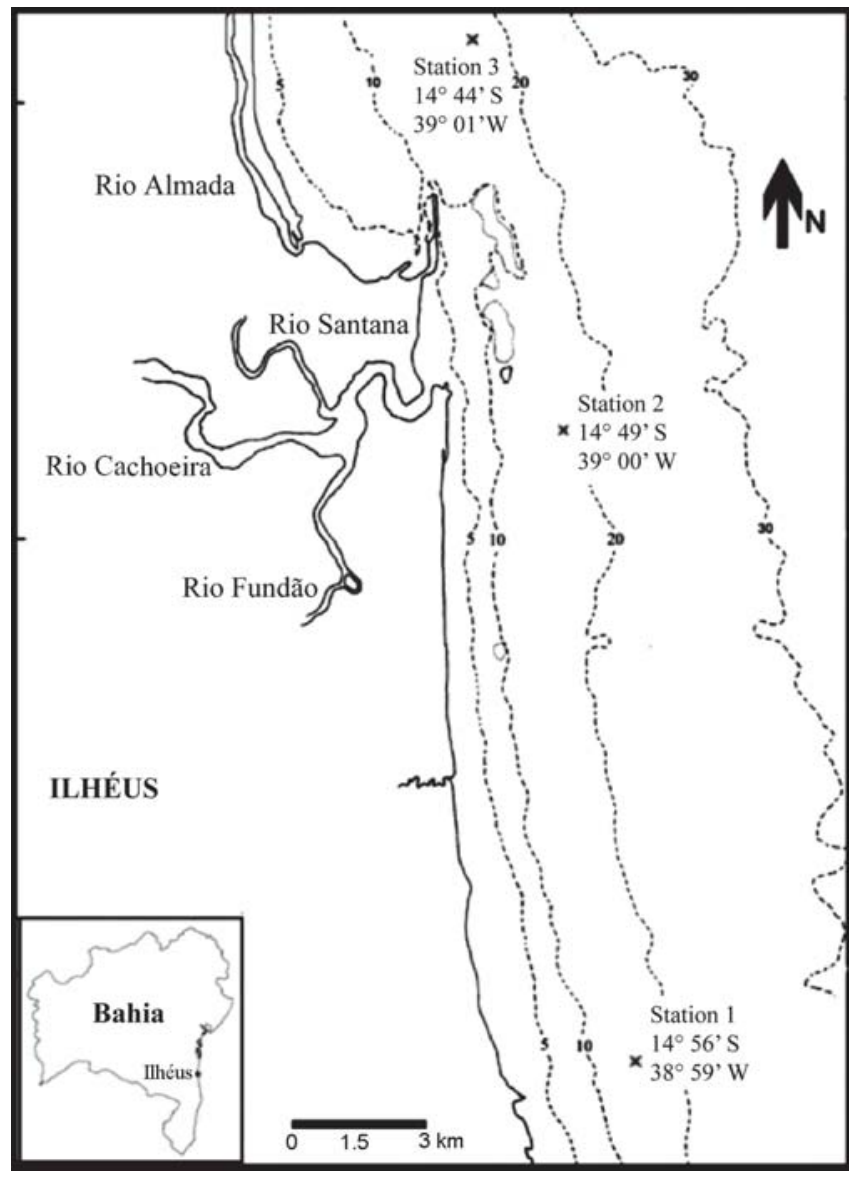

Fig. 1. Map of the studied area (Ilhéus city, Bahia State, Brazil) indicating the sample sites (x) and the isobaths (dashed lines). 
width (an average of $18 \mathrm{~km}$ ), and is characterized by sand and sandy mud in the shallower regions (up to $10 \mathrm{~m}$ in depth), followed by mixed muddy sediments that can reach $20 \mathrm{~m}$ deep. Sand and muddy bio-detritus sediments are predominant close to the rocky bodies and in the continental shelf break. Formation of reefs is present on the shoreline south of the Ilhéus city (Martin et al., 1980; Bittencourt et al., 2000).

Sampling was conducted monthly from March, 2003 to February, 2005 at three stations at a depth of 16 m (Fig. 1). Specimens were caught using a $0.55 \times 1.00 \mathrm{~m}$ bottom trawl net, with $22 \mathrm{~mm}$ stretch mesh in the body and wings and $16 \mathrm{~mm}$ bar mesh at the cod end. It was pulled for 30 min using a boat $8 \mathrm{~m}$ long and with $20 \mathrm{HP}$.

Biological material in the field was kept in ice. In the laboratory, samples were stored in a freezer $\left(-20^{\circ} \mathrm{C}\right)$ until processing. Fishes were identified according to Menezes \& Figueiredo (1980), and total length ( $\mathrm{mm})$ and weight (g) was recorded for each specimen. Whenever possible, gonads were weighed and the stage of maturity was macroscopically observed, according to the criteria proposed by Vazzoler (1996): I - immature; II - developing; III - ripe; and IV - post-spawning. The stomachs were removed and preserved in 70\% alcohol. Voucher specimens were deposited in the ichthyological collection (ISPA 01) of the Laboratory of Biological Oceanography (Laboratório de Oceanografia Biológica - UESC).

The standardized Morisita index "Ip" was used to study the population distribution pattern in the examined area, which varies from -1.0 to 1.0 with a $95 \%$ confidence limit, following the classification: aggregate population distribution pattern (Ip $\geq 0.5)$, uniform pattern $(\mathrm{Ip} \leq-0.5)$ and random pattern $(0.5$ $<$ Ip $<-0.5)($ Krebs, 1999).

Variations in the number of individuals between stations and seasons (summer, autumn, winter and spring) were compared using analysis of variance (ANOVA), interaction among variables (stations and seasons) were tested and the values were initially standardized as square root +0.5 (Zar, 1996).

Average length of first maturity $\left(\mathrm{L}_{50}\right)$ using a non-linear adjustment, sex ratio and length/weight relationships were estimated for the whole group of data (Zar, 1996).

The stomach contents of 241 individuals caught between May and December of 2004 were analyzed using a stereoscopic microscope. Food items were identified to the lowest possible taxonomic level and the qualitative and quantitative characterization was performed by observing the number and frequency of occurrence of food items, as defined by Hyslop (1980), Fonteles-Filho (1989) and Zavala-Camin (1996). Due to the high degree of digestion, it was not possible to determine weight or volume of food items, which did not allow the calculation of relative importance indexes.

\section{Results}

The species I. parvipinnis was the most abundant in number of individuals (1290) of all the captured fish species, corresponding to almost $20 \%$ of the fish assemblage captured as bycatch.
The standardized Morisita index ("Ip") was 0.53 , indicating an aggregate population distribution pattern $(95 \%$ confidence level).

Significant differences were observed in the abundance of I. parvipinnis throughout the year (Table 1), with the highest average values recorded in the winter (Fig. 2). A total of

Table 1. Analysis of variance (ANOVA) of the number of $I$. parvipinnis individuals in the region of Ilhéus (BA) among stations and seasons of the year and their interactions. V.S: Variance sources, SQ: sum of squares, DF: degrees of freedom, MS: mean squares, F: value of $F$ test. Bold values denote significant values $(\mathrm{p}<0.05)$.

\begin{tabular}{lccccc}
\hline \multicolumn{1}{c}{ V.S } & SQ & DF & MS & F & p \\
\hline Stations & 2,297 & 2 & 1,148 & 0.132 & 0.8764 \\
Seasons & 208,400 & 3 & 69,467 & 8.002 & $\mathbf{0 . 0 0 0 2}$ \\
Seasons * Station & 44,214 & 6 & 7,369 & 0.849 & 0.5386 \\
Error & 442,762 & 51 & 8,682 & & \\
\hline
\end{tabular}

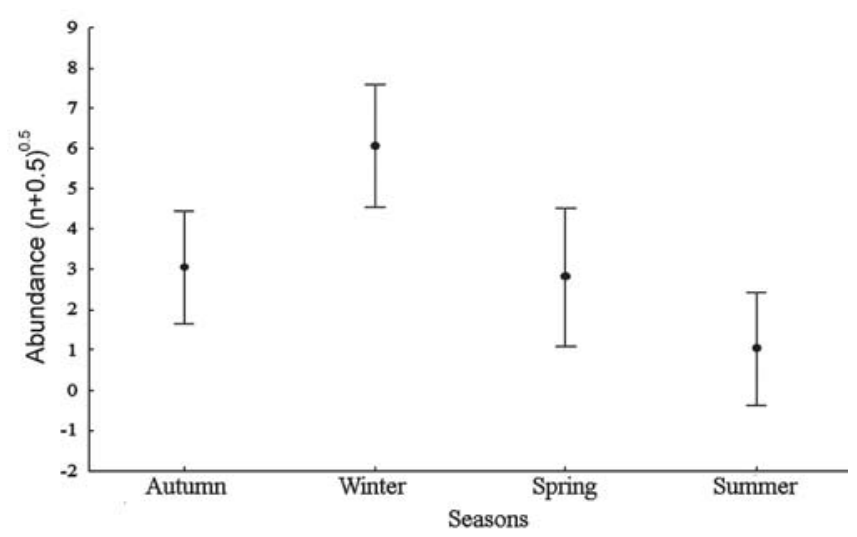

Fig. 2. Adjusted average of number of Isopisthus parvipinnis individuals captured over the seasons on coast of Ilhéus, Bahia, Brazil.

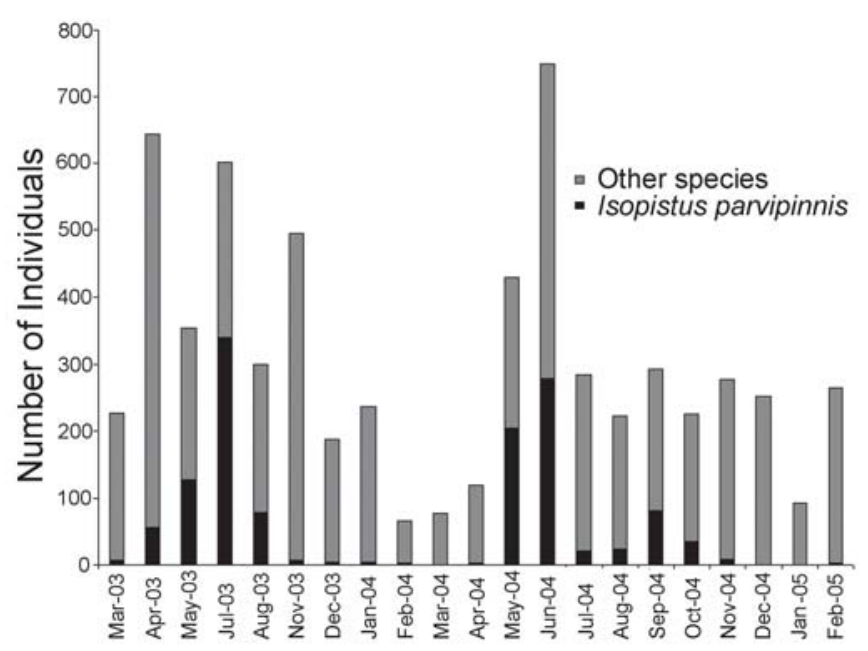

Fig. 3. Total number of Isopisthus parvipinnis individuals captured per sampling month along the coast of Ilhéus, Bahia, Brazil. 


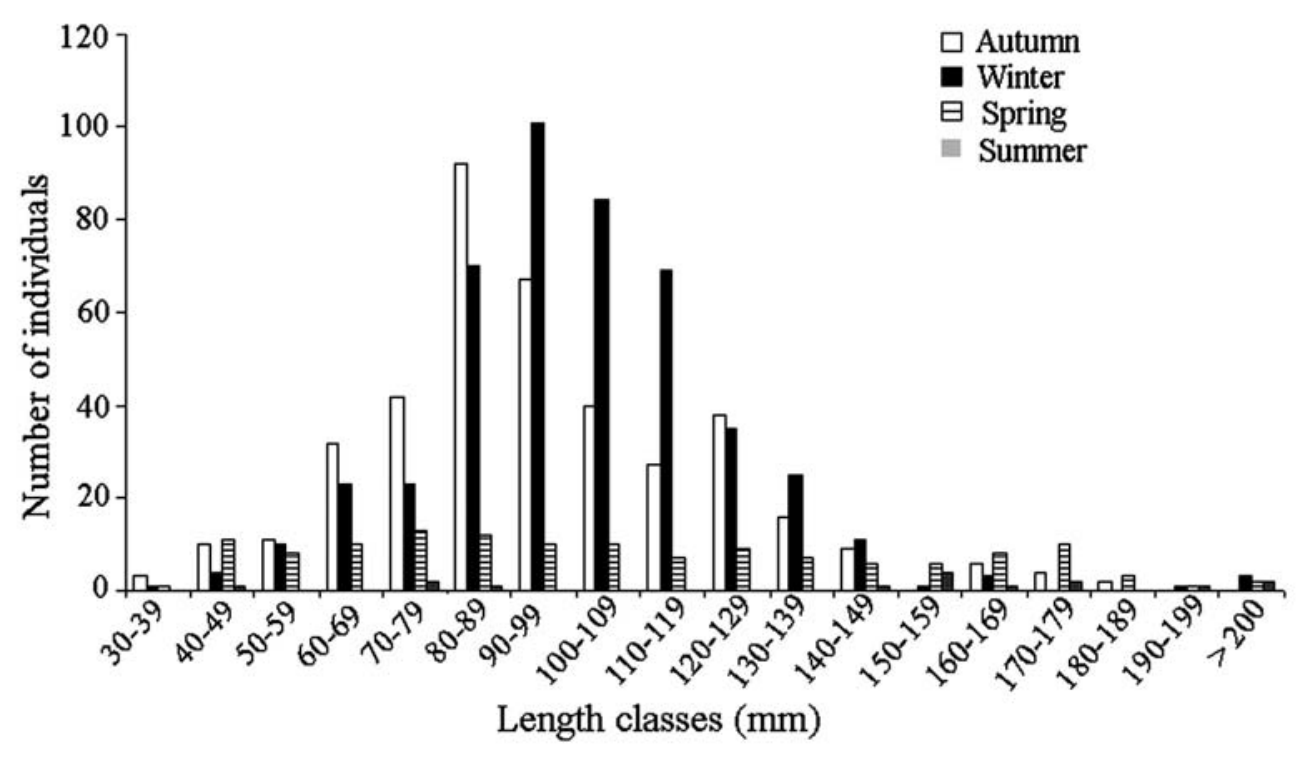

Fig. 4. Number of Isopisthus parvipinnis individuals $(\mathrm{n}=990)$ per length category across those captured along the coast of Ilhéus, Bahia, Brazil.

1142 individuals (approximately $89 \%$ of all the captured specimens) were recorded in autumn and winter. In the summer, only 15 individuals were captured. The months with the highest abundance were May, June and July (end of autumn and beginning of winter), during which the species corresponded to more than $40 \%$ of all captured ichthyofauna (Fig. 3 ). No significant differences were observed in the number of individuals among the three stations or there was no interaction between stations and seasons (Table 1).

Total length of the individuals varied from 30 to $228 \mathrm{~mm}$, with modes of 80 and $90 \mathrm{~mm}$. A seasonal variation was recorded in the relative frequency of size distribution. In the autumn, the mode class was $80 \mathrm{~mm}$ and $90 \mathrm{~mm}$ in winter,

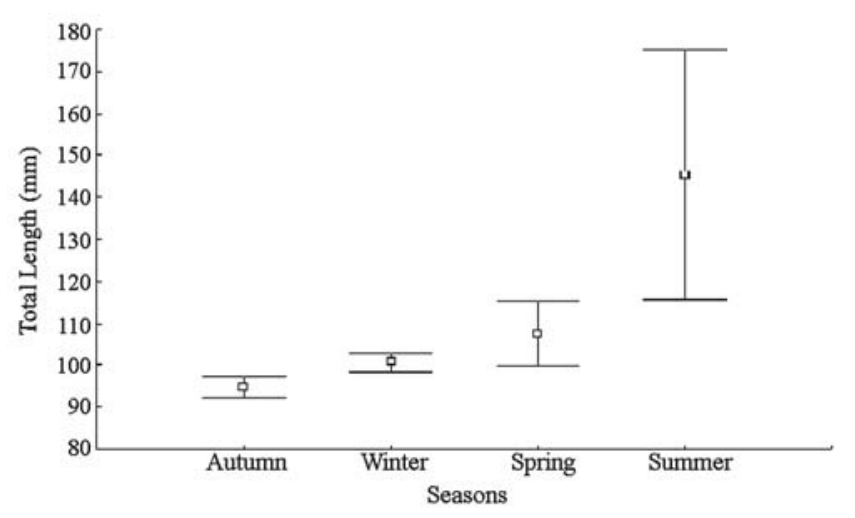

Fig. 5. Average length of Isopisthus parvipinnis and confidence interval of $95 \%(n=990)$ across seasons of those individuals captured along the coast of Ilhéus, Bahia, Brazil. whereas no length class modes were present in spring or summer (Fig. 4). The highest average length of individuals was recorded in the summer $(145 \mathrm{~mm} \pm 54.1)$ and the lowest was noted in autumn (95 $\mathrm{mm} \pm 25.9)$ (Fig. 5). Similarly, this pattern was repeated for average individual weight $(35.0 \mathrm{~g} \pm$ 28.6 and $9.0 \mathrm{~g} \pm 8.1$, respectively).

The estimated length of the first maturation $\left(\mathrm{L}_{50}\right)$ for grouped sexes of I. parvipinnis was $159 \mathrm{~mm}$ and the length in which all captured individuals were mature $\left(\mathrm{L}_{100}\right)$ was $220 \mathrm{~mm}$ (Fig. 6). Almost 95\% of all captured individuals were under the estimated length for first maturation.

Regarding the entire sampling period, the sex ratio in the area was 1.5 males for each female. From the total of 55 adult individuals (representing 5\% of total individuals), only 2 females and 11 males showed ripe gonads (stage III). No gonads were observed at post-spawning stage (stage IV). The highest number of adults was captured in the summer (73\%) and the lowest was captured in the winter $(2 \%)$. Immature individuals (stage I) were present throughout the entire sampling period but were more abundant in the winter.

The total length/weight relationship of the samples indicates a negative pattern of allometric growth $(\mathrm{a}=0.00002, \mathrm{~b}=$ 2.86 and $\mathrm{r}^{2}=0.967$ ) (Fig. 7).

Of the 241 analyzed stomachs, 19 were empty. A total of 10 food items were identified (Table 2) other than the presence of parasite (Nematode; $\mathrm{FO}=1 \%$ ). Regarding the frequency of occurrence, Decapoda Dendobranchiata and digested organic matter were predominant. Furthermore, Decapoda Dendobranchiata was the most representative category concerning numeric frequency, followed by Teleostei. 


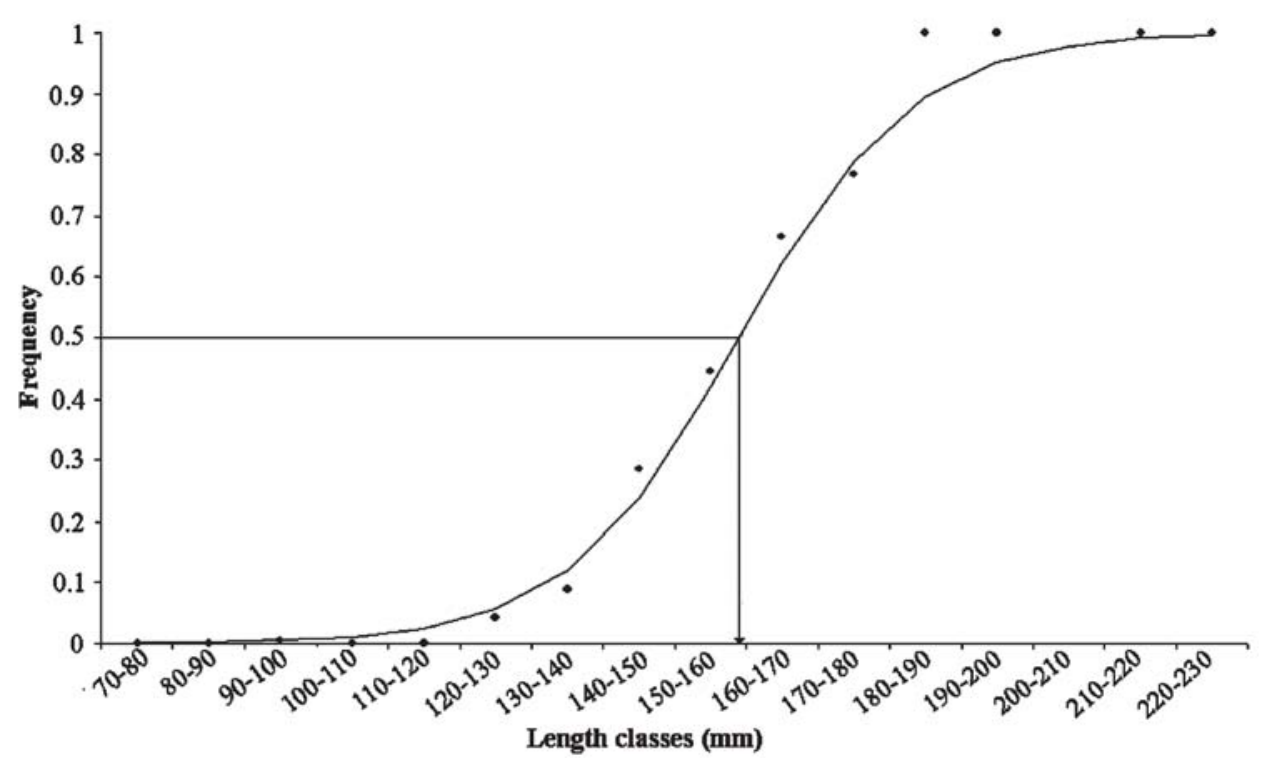

Fig. 6. Estimated length of first maturation $\left(\mathrm{L}_{50}\right)$ of Isopisthus parvipinnis $(\mathrm{n}=990)$ in Ilhéus, Bahia, Brazil.

\section{Discussion}

Isopisthus parvipinnis has also been recorded as being abundant in other regions of Brazil (Sudene, 1969; Coelho et al., 1986; Paiva-Filho et al., 1987; Giannini \& Paiva-Filho, 1994; Bail \& Branco, 2003).

The aggregate pattern observed for I. parvipinnis, possibly reflects a patchy distribution of food resources. This distribution pattern can occur in response of the different habitat locations and seasons, due to reproductive processes and resource use optimization. The increase in competition resulting from a larger number of individuals is counterbalanced by a higher survival of the school (Gerking, 1994).
Considering temporal abundance differences, average length of individuals and frequency of adults, both autumn and winter were characterized by a higher number of individuals, mainly immature and small in size. This pattern was equally recorded by Giannini \& Paiva Filho (1994) in Baía de Santos. On the other hand, in the spring and summer the abundance of I. parvipinnis was reduced and the few individuals captured were predominantly adults and longer in length. From these results, it can be supposed that during autumn and winter, immature I. parvipinnis occupy the inner shelf $(16 \mathrm{~m})$ of Ilhéus for growth, characterizing this period as the recruitment time of the species, whereas in the spring and summer adult individuals move to other areas for reproduction.

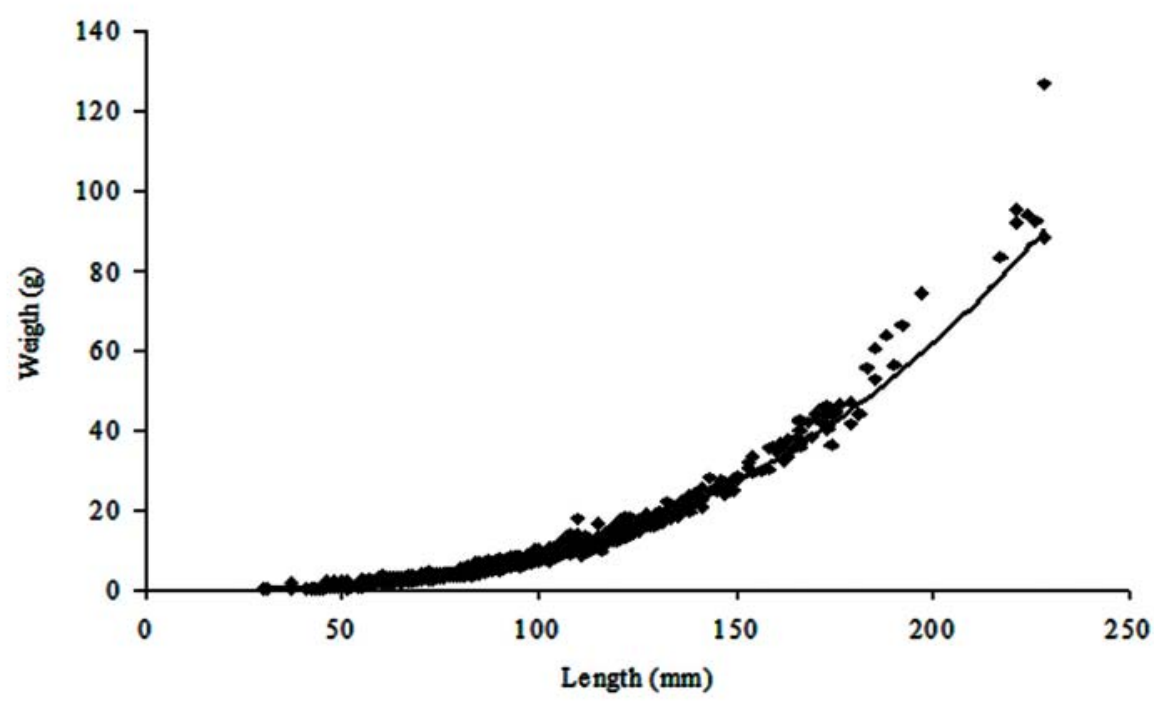

Fig. 7. Length/weight relationships of the species Isopisthus parvipinnis $(\mathrm{n}=990)$ in Ilhéus, Bahia. 
Table 2. Food categories for I. parvipinnis on the coast of Ilhéus - BA $(\% \mathrm{~N}=$ numeric frequency; $\% \mathrm{O}=$ frequency of occurrence).

\begin{tabular}{lcc}
\hline FOOD CATEGORIES & $\% \mathrm{~N}$ & $\% \mathrm{O}$ \\
\hline Decapoda Dendobranchiata & 65 & 36 \\
Dissolved organic matter (DOM) & - & 30 \\
Teleostei & 27 & 25 \\
Remainders of Crustacea & - & 15 \\
Teleostei scales & 2 & 3 \\
Decapoda & 2 & 3 \\
Unidentified matter & 1 & 1 \\
Cephalopod & 1 & 1 \\
Isopod Crustacea & 1 & 1 \\
Amphipod Crustacea & 1 & 1 \\
\hline TOTAL & 100 & - \\
\hline
\end{tabular}

Similar conclusions were obtained for other regions of the Brazilian coastline. On the coast of São Paulo, Coelho et al. (1988) recorded the months of March and April as having the highest recruitment of I. parvipinnis. Recruitment during autumn and winter, and reproduction and spawning between spring and summer, were also suggested by Chaves et al. (1998) and Giannini \& Paiva Filho (1994). However, this last work also supposes the existence of a prolonged recruitment period, from summer to winter, due to the observation of two abundance peaks of the young individuals. Soares (pers. comm.) suggests that spawning of this species, between Cabo Frio (RJ) and Torres (RS) probably occurs during the spring and that recruitment therefore occurs between summer and winter. For the coast of Ilhéus, the results seem to suggest only one recruitment period of this species between autumn and winter.

A study conducted in the Baía de Guaratuba (Paraná) by Chaves et al. (1998) indicates the absence of young individuals and the predominance of adults in the mangrove and estuary areas. It is suggested that the adults of this species move to the mangrove areas and bays, present on the coast of Ilhéus, during the spring and summer, and that a movement to deeper areas of the continental shelf is improbable. Although this hypothesis needs to be tested, it would explain the low abundance and absence of I. parvipinnis in the sampling carried out during these seasons of the year.

The estimated length of first maturation represents the size in which $50 \%$ of individuals initiate their reproductive cycle and is therefore used as a reference to determine the minimum size of resource exploitation, which, consequently, can be useful when choosing the adequate fishing methods (Vazzoler, 1996). On the coast of Ilhéus, there was a predominance of captured I. parvipinnis individuals with sizes under $\mathrm{L}_{50}$ and a low abundance of adults. As the method of capture used in this study followed the strategy adopted by shrimp trawl fisheries developed in the region, it can be concluded that this collection mainly targets the juvenile stock of $I$. parvipinnis.

The number of young individuals in the composition of bycatch is large in various regions of the country (Coelho et al., 1986; Viana et al., 2000; Graça-Lopes et al., 2002 and Chaves et al., 2003) and in the world (Alverson et al., 1994). Removal of immature fractions of the population by means of capture as bycatch can cause a decrease in the spawning stock potential (Perra, 1992; Vazzoler, 1962). A massive capture of $I$. parvipinnis individuals on the coast of Ilhéus in the recruitment period can directly interfere with the restitution of the population of this species and with the maintenance of its ecological functions.

The dispersal of length/weight data observed and the value of "b" found $(b<3)$ are characteristics of a species with a negative allometric type of growth. According to Vazzoler (1991), low values for the allometric growth rate are expected for populations residing in open coastal areas, such as the study area. Chaves et al. (1998) and Giannini \& Paiva Filho (1994) also noted an allometric growth for the species although the values found in these studies were higher than 3 . In nature, there is a great variation in the factors mass of the gonads and stomach contents, and the different size ranges analyzed in these studies are factors that cause contrasting results for the value of "b" (Chaves et al. 1998).

Regarding the I. parvipinnis diet, a predominance of Decapoda Dendobranchiata and Teleostei, indicates that this species has a restricted food range. Studies conducted in southern and south-eastern regions of the Brazilian coastline record a broader diet for this species, although only the Teleostei and Decapoda Natantia categories have been shown to be important (Soares, 1989; Soares \& Vazzoler, 2001). For the coast of Ilhéus, I. parvipinnis is stenophagic according to definitions presented by Zavala-Camin (1996), and carnivorous, where at least juveniles tend to consume crustaceans.

Regarding the conservation of the resources found in the bycatch, our study suggests that this sampling area could be an important growth area for I. parvipinnis. In order to protect this population, we suggest that a non-fishing ("defeso") period for sea-bob shrimp (X. kroyeri) be established during the winter months for protection of I. parvipinnis recruits. Alternatives can also be adopted for the reduction of the bycatch death rate, such as the introduction of net escape devices, a decrease in trawling time and changes in the fishing period and in banned areas. Nonetheless, only the implementation of a fishery policy capable of integrating the characteristics of the target species with those of the fauna found in the same environment could minimize the magnitude of this problem.

\section{Acknowledgments}

The authors wish to thank the CNPq for funding the project, "A fauna acompanhante da pesca do camarão na costa de Ilhéus (BA): estudos para regulação e exploração do camarão e estratégias para a sua conservação (AFAPESCA), $\mathrm{N}^{\circ}$ 478660/2003-0," and scientific initiation (CNPq-PIBIC) (M. N. S.). We thank FAPESB for granting a Master's Scholarship (L.E.M) and Capes for a Master's Scholarship in the Social Demand modality (R.M.R). The authors also wish to thank 
the professors Dr. Lucy Soares (Instituto Oceanográfico USP) and Dr. Guisla Boehs (Universidade Estadual de Santa Cruz) for their contributions in the discussion of the results.

\section{Literature Cited}

Alverson, D. L., M. H. Freeberg, J. G. Pope \& S. A. Murawski. 1994. A global assessment of fisheries bycatch and discards. FAO Fishery Technological Paper, 339:233.

Bahia. 2001. Diagnóstico das bacias hidrográficas dos Rios Cachoeira e Almada: caracterização climatológica. Governo do Estado da Bahia: SEINFRA. Superitendência de Recursos Hídricos (SRH). Salvador. v. I, Tomo III. 86p.

Bail, G. C. \& J. O. Branco. 2003. Ocorrência, abundância e diversidade da ictiofauna na pesca do camarão sete-barbas, na região de Penha, SC. Notas Técnicas Facimar, 7: 73-82.

Bittencourt, A. C. S. P., J. M. L. Dominguez, L. Martin \& I. R. Silva. 2000. Patterns of sediment dispersion coastwise the state of Bahia - Brazil. Anais da Acadêmia Brasileira de Ciências, 72(2): 271-287.

Branco, J. O. 2001. Descarte da pesca do camarão sete-barbas como fonte de alimento para aves marinhas. Revista Brasileira de Zoologia, 18(1): 293-300.

Carpenter, K. E. (ed.). 2002. The living marine resources of the Western Central Atlantic (Opistognathidae to Molidae), sea turtles and marine mammals 3(2). FAO Species Identification guide for fishery purposes and American society of ichthyologists and herpetologists special publication, n. ${ }^{\circ} 5$, Rome, FAO, 2127p.

Cervigón, F., R. Cipriani, W. Fischer, L. Garibaldi, M. Hendrickx, A. J. Lemus, R. Márquez, J. M. Poutiers, G. Robaina \& B. Rodriguez. 1992. Guía de campo de las especies comerciales marinas y de aquas salobres de la costa septentrional de Sur América. Fichas FAO de identificación de especies para los fines de la pesca. Rome, FAO, 513 p.

Chaves, P. T., G. Cova-Grando \& C. Calluf. 2003. Demersal ichthyofauna in a continental shelf region on the south coast of Brazil exposed to shrimp trawl fisheries. Acta Biologica Paranaense, 32: 69-82.

Chaves, P. T., A. Rickli \& J. L. Bouchereau. 1998. Strategie d'occupation de la mangrove de la Baie de Guaratuba (Bresil) par le sciaenidae predateur Isopisthus Parvipinnis (Teleostei, Pisces). Cahiers de Biologie Marine, 15(1): 63-71.

Coelho, J. A. P., R. Graça-Lopes, E. S. Rodrigues \& A. Puzzi. 1988. Aspectos biológicos e pesqueiros de Isopisthus parvipinnis (Cuvier, 1830), Teleostei, Perciformes, Scianidae, presente no rejeitado da pesca artesanal dirigida ao camarão sete-barbas (São Paulo, Brasil). Boletim do Instituto de Pesca, 15(1): 99-108.

Coelho, J.A.P., A. Puzzi, R. Graça-Lopes, E. S. Rodrigues \& O. PrietroJr. 1986. Análise da rejeição de peixes na pesca artesanal dirigida ao camarão sete-barbas (Xiphopenaeus kroyeri) no litoral do estado de São Paulo. Boletim do Instituto de Pesca, 13(2):51-61.

Dominguez, J. M. L. \& A. C. S. P. Bittencourt. 1994. Utilização de padrões de sedimentação costeira como indicadores paleoclimáticos naturais (PROXIES). Revista Brasileira de Geociências, 24(1): 3-12.

Fonteles-Filho, A. A. 1989. Recursos pesqueiros: biologia e dinâmica populacional. Fortaleza, Imprensa Oficial do Ceará, 296p.

França, A. M. C. 1979. Geomorfologia da margem continental Leste Brasileira e da bacia oceânica adjacente. Série Projeto REMAC, 7: 92-123.
Gerking, S. D. 1994. Feeding ecology of fish. San Diego, Academic press, $416 \mathrm{p}$.

Giannini, R. \& A. M. Paiva-Filho. 1994. Aspectos biológicos de Isopisthus parvipinnis (Perciformes, Sciaenidae) na baía de Santos, SP, Brasil. Revista Brasileira de Biologia, 54(1): 135-145.

Graça-Lopes, R., A. R. G. Tomás, S. L. S. Tutui, E. SeverinoRodrigues \& A. Puzzi. 2002. Fauna acompanhante da pesca camaroneira no litoral do estado de São Paulo, Brasil. Boletim do Instituto de Pesca, 28(2): 173-188.

Gulland, J. A. 1966. Manual of sampling and statistical methods for fisheries biology. Part 1. Sampling methods. FAO Manual of Fisheries Science 3, Rome, FAO. 87p.

Haimovici, M. \& J. T. Mendonça. 1996. Descartes da fauna acompanhante na pesca de arrasto de tangones dirigida a linguados e camarões na plataforma continental do sul do Brasil. Atlântica, 18: 161-177.

Hyslop, E. J. 1980. Stomach contents analysis - a review of methods and their application. Journal of Fish Biology, 17(4): 411-429.

Krebs, C. J. 1999. Ecological Methodology. $2^{\circ}$ ed., New York, A. Wesley Longman. 620p.

Martin, L., A. C. S. P. Bittencourt, G. S. Vilas Boas \& J. M. Flexor. 1980. Mapa geológico e texto explicativo do quaternário costeiro do estado da Bahia - Esc. 1: 250.000. Salvador (BA): SME/ COM. 60p.

Martin, L., J. M. L. Dominguez \& A. C. S. P. Bittencourt. 1998. Climatic control of coastal erosion during a sea-level fall episode. Anais da Acadêmia Brasileira de Ciências, 70: 249-266.

Menezes, N. A. \& J. L. Figueiredo. 1980. Manual de peixes marinhos do Sudeste do Brasil. Teleostei (3). Museu de Zoologia, Universidade de São Paulo. São Paulo, 4: 96p.

Paiva-Filho, A. M., R. Giannini, F. B. Ribeiro-Neto \& J. M. M. Schimiegelow. 1987. Ictiofauna do complexo baía-estuário de Santos e São Vicente, SP, Brasil. Relatório Interno do Instituto Oceanográfico, 17: 1-10.

Paiva-Filho, A. M. \& J. M. M. Schmiegelow. 1986. Estudo sobre a ictiofauna acompanhante da pesca do camarão sete-barbas (Xiphopenaeus kroyeri) nas proximidades da Baía de Santos SP. I. Aspectos quantitativos. Boletim do Instituto Oceanográfico, 34: 78-85.

Perez, J. A. A., P. R. Pezzuto, L. F. Rodrigues, H. Valentini \& C. M. Vooren. 2001. Relatório da reunião técnica de ordenamento da pesca de arrasto nas regiões sudeste e sul do Brasil. Notas Técnicas Facimar, 5: 1-34.

Perra, P. 1992. By-catch reduction devices as a conservation measure. Fisheries, 17(1): 28-29.

Santos, M. C. F. 2000. Diversidade ecológica da ictiofauna acompanhante nas pescarias de camarões em Tamandaré (PernambucoBrasil). Boletim Técnico Científico Cepene, 8(1): 165-183.

Soares, L. S. H. 1989. Diet of Isopisthus parvipinnis (Teleostei: Sciaenidae) in baia de Santos, São Paulo. Boletim do Instituto Oceanográfico, 37(2): 95-105.

Soares, L. S. H. \& A. E. A. M. Vazzoler. 2001. Diel changes in food and feeding activity of sciaenid fishes from the southwestern Atlantic, Brazil. Revista Brasileira de Biologia, 61(2): 197-216.

Sudene. 1969. Departamento de Recursos Naturais. Projeto Akarôa. Documentos Pesca, 19: 1-48.

Vazzoler, A. E. A. M. 1962. Sobre a primeira maturação sexual e destruição de peixes imaturos. Boletim do Instituto Oceanográfico, 12(2): 5-38.

Vazzoler, A. E. A. M. 1991. Síntese de conhecimento sobre a biologia da corvina, Micropogonias furnieri (Desmarest, 1823), da costa do Brasil. Atlântica, 13: 55-74. 
Vazzoler, A. E. A. M. 1996. Biologia da reprodução de peixes teleósteos: teoria e prática. Maringá, EDUEM. 169p.

Vianna, M. 2001. Camarão: pescado objetivo ou captura acessória? Sugestões para o gerenciamento da pescaria. Notas Técnicas Facimar, 5: 47-49.

Vianna, M., A. R. G. Tomas \& J. R. Verani. 2000. Aspects of the biology of the Atlantic midshipman, Porichthys porosissimus (Teleostei, Batrachoididae): an important by-catch species of shrimp trawling off southern Brazil. Revista Brasileira de Oceanografia, 48(2): 131-140.

Zar, J. H. 1996. Biostatistical Analysis. New Jersey: Prentice-Hall, $662 \mathrm{p}$.

Zavala-Camin, L. A. 1996. Introdução aos estudos sobre alimentação natural em peixes. Mariangá, EDUEM, 129p.

Accepted December 2007

Published 31 March 2008 